\title{
Methane anomalies over TAG hydrothermal field on Mid Atlantic Ridge
}

\author{
by J. L. Charlou, ${ }^{1}$ P. Rona ${ }^{2}$ and H. Bougault ${ }^{1}$
}

\begin{abstract}
Black smoker type hydrothermal venting was discovered in July 1985 at the TAG hydrothermal field in the rift valley of the Mid Atlantic Ridge near $26 \mathrm{~N}$. We present here, the first methane profiles in the seawater column over this black smoker along with methane profiles away from the black smokers for comparison. The $\mathrm{CH}_{4}$ plume, spreading over $400 \mathrm{~m}$ above the seafloor, shows a maximum concentration of $105 \mathrm{nl} / 1$ at $3450 \mathrm{~m}$ ( $238 \mathrm{~m}$ above the bottom), correlated with a positive temperature anomaly $\left(0.02^{\circ} \mathrm{C}\right) . \mathrm{CH}_{4}$ concentrations up to $2422 \mathrm{nl} / \mathrm{l}$, correlated with a huge positive increase of in situ temperature $\left(0.349^{\circ} \mathrm{C}\right)$, have been measured in samples taken $5 \mathrm{~m}$ above the sea floor, showing an important $\mathrm{CH}_{4}$ input in this slow spreading site which is similar to inputs from fast spreading sites like the East Pacific Rise.
\end{abstract}

\section{Introduction}

Injection of hydrothermal fluids to the ocean occurs in the axial zone of ocean ridges by discharge from vents. Hydrothermal solutions have been studied in samples recovered by submersible in black smokers at several sites on the East Pacific Rise (Edmond et al., 1982; Michard et al., 1984). Although these samples were more or less mixed with sea water, it has been demonstrated that the end-member fluids are highly enriched in the gases helium, methane and hydrogen (Welhan and Craig, 1979, 1983) and in dissolved iron and manganese. Methane in hydrothermal solutions is generally believed to result from degassing of the mantle or from abiogenic water-rockinteraction (Welhan and Craig, 1983), as well as from biogenic production by bacteria (Lilley et al., 1983) and thermocatalysis of organic matter in sediments (Welhan and Lupton, 1987). Extrapolated end-member fluids have $\mathrm{CH}_{4}$ concentrations ranging from $3.4 \mu \mathrm{M} / \mathrm{I}$ at the Galapagos spreading center (Lilley et al., 1979) to $80 \mu \mathrm{M} / 1$ at the $11 \mathrm{~N}$ and $13 \mathrm{~N}$ EPR hydrothermal vent fields (Welhan et al., 1984). $\left(1 \mu \mathrm{M} \mathrm{CH}_{4}=\right.$ 2.24. $10^{-2} \mathrm{ml} / 1 \mathrm{CH}_{4}$ STP.)

Because of huge enrichment factors and in spite of dilution of hydrothermal solutions by sea water, hydrothermal activity produces some concentration anomalies

1. IFREMER, Centre de Brest, BP 337, 29273 Brest Cedex, France.

2. NOAA, Atlantic Oceanographic and Meteorological Laboratory, 4301 Rickenbacker Causeway, Miami, Florida, 33[49, U.S.A. 
in the deep ocean waters. As for helium and manganese, excess methane in the seawater column persists for a sufficiently long time to use these anomalies to detect active hydrothermal areas. Emission from the world oceanic ridge system, estimated by extrapolation from the East Pacific Rise data (Welhan and Craig, 1979, 1983), amounts to $1.6 \cdot 10^{8} \mathrm{~m}^{3}$ of $\mathrm{CH}_{4}$ a year. The mean concentration of deep ocean methane is only about $3 \cdot 10^{-6} \mathrm{ml} \mathrm{kg}^{-1}$ in deep Pacific waters and $6 \cdot 10^{-6} \mathrm{ml} \mathrm{kg}^{-1}$ in deep Atlantic waters (Lamontagne et al., 1973). Consequently, the calculated average global injection rate of $\mathrm{CH}_{4}$ into the oceans indicates a residence time of the order of 30 years, implying that consumption of $\mathrm{CH}_{4}$ in the water column must be rapid.

Over the East Pacific Rise (fast spreading) the existence of submarine hydrothermal convection systems has been confirmed by the discovery of hydrothermal plumes over the Galapagos spreading center (Weiss, 1977), 13N (Boulegue et al., 1980), 21N (Lupton et al., 1980), 15S (Lupton and Craig, 1981), Juan de Fuca Ridge (Normark et al., 1982; Baker et al., 1985) and Guaymas Basin (Londsdale et al., 1980). Evidence for the existence of hydrothermal plumes at these sites has been obtained by physical measurements of water temperature anomalies, level of suspended particulate matter detected with nephelometry, and by analysis of geochemical tracers in the seawater column. Helium, manganese and, more recently, methane have helped to find and characterize the injections of mantle volatiles over these active hydrothermal zones.

Recently reported hydrothermal activity for slow spreading oceanic ridges in the North Atlantic Ocean, western Indian Ocean and northern Pacific Ocean (Gorda Ridge) suggests that hydrothermal venting may exist along all such slow spreading ridges. Previous evidence for hydrothermal activity at the Mid Atlantic Ridge from $10 \mathrm{~N}$ to $26 \mathrm{~N}$ was substantial. It was well documented by manganese concentrations in ocean water (Klinkhammer et al., 1985a), temperature anomalies (Lowell and Rona, 1976), manganese deposits (Scott et al., 1974), heat flow anomalies in the sediment column, photographic evidence, dredged rocks and enriched metalliferous sediments (Cronan et al., 1979), ${ }^{3} \mathrm{He} /{ }^{4} \mathrm{He}$ ratios in the water column (Jenkins et al., 1972, 1980), photographs of vent organisms (Rona et al., 1984; Kong et al., 1985) and more recently from $\mathrm{CH}_{4}$ anomalies in sea water between 12 and $15 \mathrm{~N}$ (Charlou et al. 1986).

The first black smoker-type hydrothermal venting at the TAG hydrothermal field in the rift valley of the Mid Atlantic Ridge near 26N was discovered in July 1985 (Rona, 1985; Rona et al., 1986). Shipboard measurements of elevated concentrations of dissolved manganese (Klinkhammer et al., 1985b) and of light scattering by suspended particulate matter in the water column (Nelsen et al., 1985; Trefry et al., 1986) indicated ongoing hydrothermal activity. A systematic survey with a deep-towed instrumented sled located the black smokers by measuring near-bottom water temperature anomalies and recording seafloor images (Rona, 1985; Rona et al., 1986). We present here the first methane profile in the seawater column over the black smokers at the TAG Hydrothermal Field, along with methane profiles away from the black 


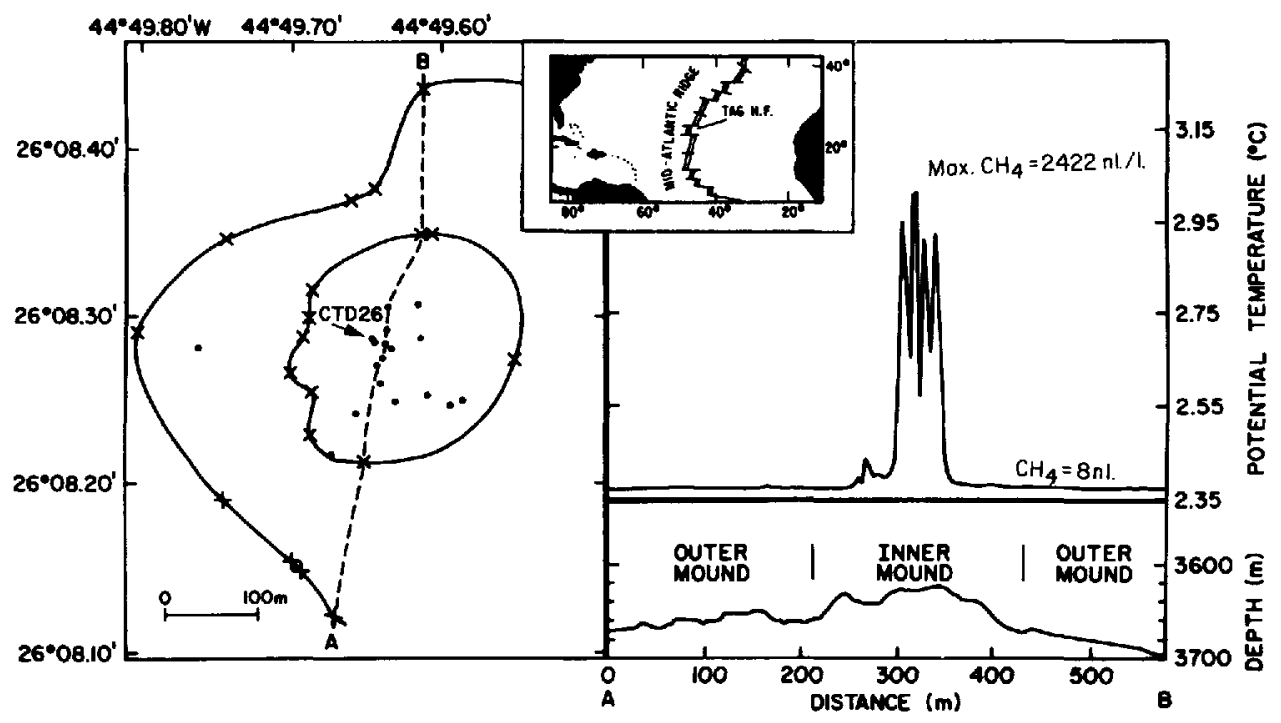

Figure 1. Illustrations showing location and characteristics of site of black smokers where water samples were recovered with CTD 26 at the TAG Hydrothermal Field in the rift valley of the Mid Atlantic Ridge (modified from Rona et al., 1986). Index map (top center) shows the location of the TAG Hydrothermal Field at the Mid Atlantic Ridge crest at latitude 26N. Illustration at left is map showing outer and inner boundaries of a mound delineated by multiple crossings $(\mathrm{x})$ with near-bottom camera-temperature-tows, the distribution of black smoker-type hydrothermal vents (dots), the location of CTD 26, and the trackline of the towed instrument transect (A-B). Illustration at lower right is a bathymetric profile across the mound along the transect (A-B). Illustration at upper right is a potential temperature profile in the water column within $10 \mathrm{~m}$ of the sea floor along the transect (A-B); the four central spikes correspond to crossings of black smokers.

smokers for comparison. The profile was made over one of a cluster of at least eleven black smokers that discharge from fractures in the central portion of a mound about $250 \mathrm{~m}$ in diameter and $50 \mathrm{~m}$ high composed primarily of hydrothermal precipitates including massive sulfides (Fig. 1) (Rona et al., 1986). The mound lies along faults at the juncture between the base of the east wall and the floor of the rift valley at water depths between 3620 and $3700 \mathrm{~m}$. The black smoker site is contiguous with a previously known zone of lower temperature hydrothermal discharge associated with iron- and manganese-rich, hydrothermal precipitates higher on the east wall of the rift valley between water depths of 2500 and $3100 \mathrm{~m}$ (Rona et al., 1984).

\section{On-board sampling and storage of samples}

During NOAA Vents Program cruise, seawater samples were collected at three stations, ST2-CTD2, ST6-CTD9, and ST6-CTD26 near $26^{\circ}$ on MAR (see locations on Fig. 3, 4) for $\mathrm{CH}_{4}$ analysis on shore. The seawater samples, obtained by using Niskin 
301 bottles mounted on a CTD/Rosette, were transferred by gravity flow into $250 \mathrm{ml}$ gas analysis bottles with teflon stopcocks. The bottles were filled from below and allowed to overflow vertically about one third of their volume in order to avoid trapping air bubbles. For long storage of the samples, it is necessary to inhibit microbial activity, by poisoning. All samples were poisoned with sodium azide when collected and shipped by air to IFREMER laboratory (Brest-France) at the end of the cruise.

Methane analyses were performed immediately after receipt in the laboratory by the modified method of Swinnerton et al. (1962), as described by Scranton and Brewer (1977). Some contamination by air may have occurred during storage. The effect of storage for periods of a few weeks to several months before analysis has been studied for Caribbean Sea and Gulf of Maine poisoned samples (Scranton and Brewer, 1977) and on poisoned Pacific water samples (Charlou, 1986b). The comparison of results obtained at sea with those obtained later in the laboratory shows small variations. All samples with high methane concentrations ( 2 to $8 \mu \mathrm{M} / \mathrm{kg}$ ) lost methane (up to $15 \%$ ). The deep samples with low methane concentrations $(0.2$ to $1 \mathrm{nM} / \mathrm{kg})$ gained methane ( 2 to $5 \%$ ). Samples which were nearly at equilibrium with the atmosphere (3.4-3.7 $\mathrm{nM} / \mathrm{kg}$ ) seemed to store well. However, it is clear that inaccuracies of this magnitude will not change the arguments to be made.

\section{3. $\mathrm{CH}_{4}$ extraction and chromatographic analysis}

Methane extraction was carried out using a modification of the technique described by Swinnerton et al. (1962). The seawater samples were transferred under methanefree helium from the $250 \mathrm{ml}$ glass bulb to a gas stripping system. The helium carrier gas was purified by passage through a molecular sieve-activated charcoal trap placed in liquid nitrogen. Dissolved gases were stripped from the sea water by purging with purified helium for ten minutes at a flow of $120 \mathrm{ml} / \mathrm{minute}$ and were concentrated on two $3 / 16$ " o.d. stainless steel traps. containing respectively activated alumina for trapping higher than $\mathrm{CH}_{4}$ hydrocarbons and activated charcoal for trapping $\mathrm{CH}_{4}$ and $\mathrm{CO}$. For this work, only $\mathrm{CH}_{4}$ was analyzed. Because of the low concentrations of $\mathrm{C}_{2}$ and $\mathrm{C}_{3}$ hydrocarbons in sea water, a volume of 1 liter is necessary to analyze these compounds. When stripping was completed, a six way gas valve was turned to place the activated charcoal trap in line with a $4 \mathrm{ft} 1 / \mathrm{s}^{\prime \prime}$ o.d. stainless steel column packed with a 60-80 mesh porapak $Q$. The trap was placed in a hot bath at $100^{\circ} \mathrm{C}$. By raising the trap temperature, the $\mathrm{CH}_{4}$ was desorbed from activated charcoal and injected into a chromatographic column placed in the oven of an Intersmat Instrument chromatograph equipped with a flame ionization detector. Peaks were recorded and integrated on a ICR IB Shimadzu integrator. System calibrations were made by injecting known values of two calibration standard gases (L'Air liquide standard $2.1 \mathrm{ppm} \pm 2 \%$ and 10 ppm $\pm 2 \%$ in helium). The limit of detection of the method is $0.5 \mathrm{nl} \mathrm{CH}_{4}$ (STP) per liter of seawater $\left(1 \mathrm{nM}=2.24 \cdot 10^{-5} \mathrm{ml} \mathrm{STP} \mathrm{CH}_{4}\right)$. 
(c)

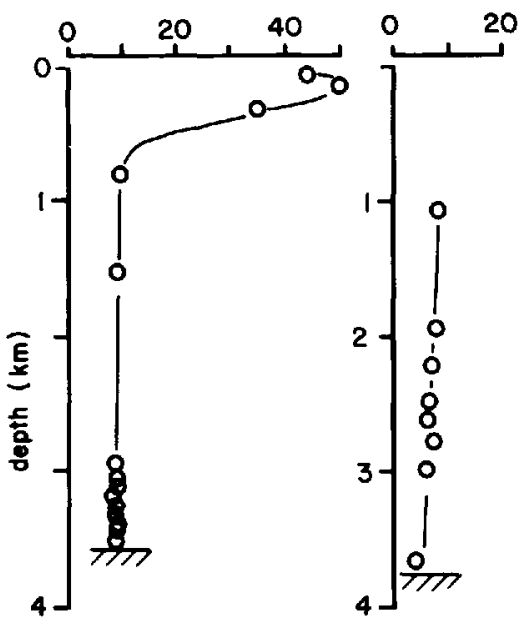

(a)

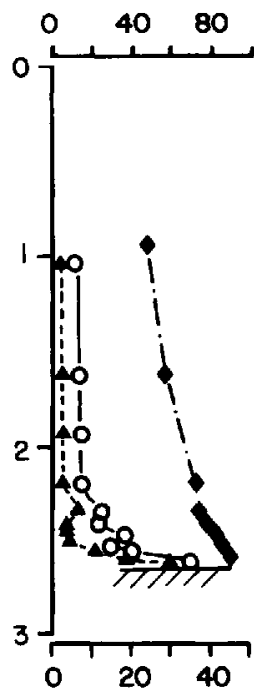

$0 \mathrm{CH}_{4}$ (nl. / I.) (d)

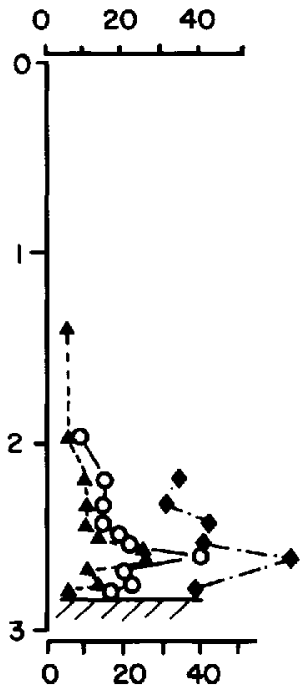

Figure 2. (a) Typical methane depth profile in Atlantic ocean without anomaly. Reference station Hy-14: $13^{\circ} 20^{\prime} 87 \mathrm{~S}-14^{\circ} 5^{\prime} 51 \mathrm{~W}$ (Charlou et al., 1986a). (b) $\mathrm{CH}_{4}$ depth profile at a control station in Pacific Ocean. Station Hy-Cy-08 (Cyatherm cruise): 15³2'04 N-101'33'72 W (Charlou et al., 1986a). (c) $\mathrm{CH}_{4}, \mathrm{He}, \mathrm{Mn}$ profiles over hot springs on the EPR at $12^{\circ} 50 \mathrm{~N}$ above the "Chain site"-Cyatherm cruise. Station Hy-Cy-01: $12^{\circ} 48^{\prime} 49 \mathrm{~N}-103^{\circ} 56^{\prime} 39 \mathrm{~W}$. (d) $\mathrm{CH}_{4}, \mathrm{He}, \mathrm{Mn}$ profiles on the EPR at $12^{\circ} 50 \mathrm{~N}$ site. This station $\mathrm{Hy}-\mathrm{Cy}-05$ was located $4 \mathrm{~km}$ west of the axis at $12^{\circ} 46^{\prime} 41 \mathrm{~N}-103^{\circ} 55^{\prime} 44 \mathrm{~W}$. The hatched lines on Figure $2 \mathrm{a}, \mathrm{b}, \mathrm{c}, \mathrm{d}$, indicate the bottom depth. Helium profiles are by Merlivat (CEA/Saclay-France).

\section{Results}

\section{a. Methane profiles in the open ocean}

Enrichment of $\mathrm{CH}_{4}$ in surface waters is a common feature. Concentrations of $\mathrm{CH}_{4}$ measured in samples from the mixed layer are commonly higher than concentrations predicted from the solubility of $\mathrm{CH}_{4}$ in sea water and known atmospheric concentrations (Lamontagne et al., 1973; Brooks et al., 1973). The methane maxima in the upper seawater column indicates the existence of biological methane production at rates much faster than physical removal (i.e. diffusion to the atmosphere) and chemical or biological consumption. Typical profiles of methane versus depth in the open ocean are presented in Figures 2a, b for Atlantic Hy-14 and Pacific Hy-Cy-08 reference stations.

From 50\% supersaturated concentrations in surface layers, $\mathrm{CH}_{4}$ contents decrease regularly with depth to $8-10 \mathrm{nl} / 1$ at $1000 \mathrm{~m}$. Deep North Atlantic waters have only 
$30 \%$ of their atmospheric equilibrium values of $\mathrm{CH}_{4}(10 \mathrm{nl} / \mathrm{l})$ and deep North Pacific waters have only $10 \%$ ( $4 \mathrm{nl} / \mathrm{l}$ ) (Scranton and Brewer, 1978). Generally, in deep waters, typical concentrations are about $4 \mathrm{nl} / \mathrm{l}$ in the Pacific and 6-8 nl/l in the Atlantic (Lamontagne et al., 1973). The value of $8 \mathrm{nl} / 1$ found at $2500 \mathrm{~m}$ at the three stations ST2-CTD2, ST6-CTD9, ST6-CTD26, near 26N on MAR is consistent with results of other authors.

\section{b. $\mathrm{CH}_{4}$ anomalies at fast spreading ridges: $E P R$}

Large levels of $\mathrm{CH}_{4}$ are found in anoxic basins (Lamontagne et al., 1973; Atkinson and Richards, 1967) and at hydrothermal sites (Kim, 1983). In the Red Sea, $\mathrm{CH}_{4}$ concentrations vary from $50 \mathrm{nl} / \mathrm{l}$ in the water column to $150 \mu \mathrm{l} / \mathrm{l}$ in brines (Burke et al., 1981). $\mathrm{CH}_{4}$ concentrations in hydrothermal end members at $10^{\circ} 50^{\prime} \mathrm{N}$ on the East Pacific Rise (EPR) (Welhan et al., 1984) are from $10^{5}$ to $10^{6}$ times greater than normal deep ocean waters. This contrast is so great that $\mathrm{CH}_{4}$ discharges on the sea floor create $\mathrm{CH}_{4}$ anomalies in deep waters.

Figure 2c presents a profile at $12^{\circ} 50^{\prime} \mathrm{N}$ on the EPR above the "Chain site"; $\mathrm{CH}_{4}$ enrichment up to $70 \mathrm{nl} / \mathrm{l}$ are observed close to the sea floor. The $\mathrm{CH}_{4}$ anomaly is still clearly detectable $4 \mathrm{~km}$ west (Fig. 2d) of the site at about the same depth. A good correlation exists between helium, manganese and methane anomalies. Helium-3, a primordial isotope of helium, has proved to be a most sensitive tracer for the hydrothermal activities. The enrichment of the isotopic ratio provides a characteristic signature for mantle volatiles (Craig and Lupton, 1981). Manganese has also been used for tracing hydrothermal plumes. Manganese shows a linear relationship with helium-3 in the water column over the $21 \mathrm{~N}$ hydrothermal system (Lupton et al., 1980).

The amplitudes of $\mathrm{CH}_{4}$ anomalies found to date vary between the different studied sites: $105 \mathrm{nl} / 1$ at Vulcan station 3 and $250 \mathrm{nl} / 1$ at Vulcan station 6 at $20 \mathrm{~S}$ EPR zone; $60 \mathrm{nl} / 1$ on the $21 \mathrm{~N} \mathrm{EPR} \mathrm{zone} \mathrm{at} \mathrm{Pluto} \mathrm{station} \mathrm{13,} \mathrm{above} \mathrm{the} \mathrm{vent} \mathrm{field,} 74 \mathrm{nl} / 1$ in Marianna trough Cepheus 82 station 20 (Kim, 1983). During the Cyatherm cruise in 1982, we measured $70 \mathrm{nl} / 1$ above a vent field located at $12^{\circ} 50^{\prime} \mathrm{N}$ on the EPR axis (Fig. 2d) and up to $40 \mathrm{nl} / \mathrm{l}$ between 12 and $15 \mathrm{~N}$ on the MAR (Charlou et al., 1986a).

\section{c. $\mathrm{CH}_{4}$ anomalies at $26 \mathrm{~N}, \mathrm{MAR}$}

Cast station ST6-CTD9 (Fig. 3). Higher than normal temperatures were detected in the bottom waters. The anomaly of temperature (about $0.05^{\circ} \mathrm{C}$ ) is very clear between $3250 \mathrm{~m}$ and $3561 \mathrm{~m}$. In the last $300 \mathrm{~m}$ above the sea floor, the variability of temperature recording increased significantly. No such anomalies were observed at site CTD2 (abyssal plain).

Between water depth of $2500 \mathrm{~m}\left(\mathrm{CH}_{4}=8 \mathrm{nl} / \mathrm{l}\right)$ and $3578 \mathrm{~m}, \mathrm{CH}_{4}$ concentration increases progressively from $25 \mathrm{nl} / 1$ at $3000 \mathrm{~m}$, to $57 \mathrm{nl} / \mathrm{l}$ at $3165 \mathrm{~m}$ and $78 \mathrm{nl} / \mathrm{l}$ at $3417 \mathrm{~m} . \mathrm{A} \mathrm{CH}_{4}$ plume has risen $400 \mathrm{~m}$ above the sea floor. The observed anomalies are 

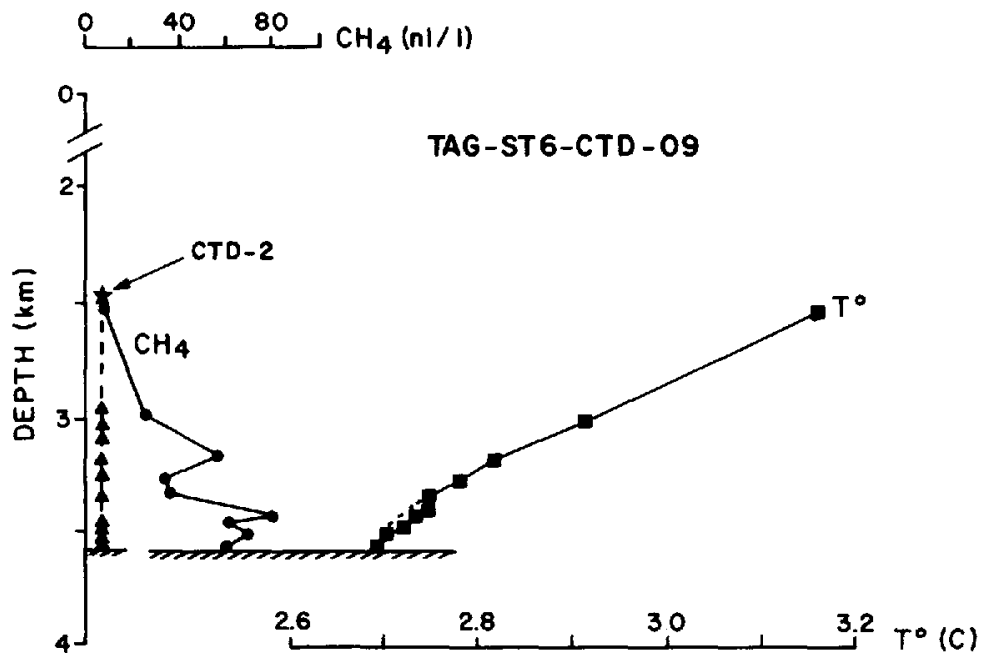

Figure 3. Cast station ST6-CTD9: Lat: $25^{\circ} 50.60^{\prime} \mathrm{N}$-Long: $42^{\circ} 33.60^{\prime} \mathrm{W}$. In situ temperature $\left({ }^{\circ} \mathrm{C}\right)$ and methane concentration $(\mathrm{nl} / 1)$ are represented versus depth $(\mathrm{km})$. The hatched lines indicate the bottom depth $(3578 \mathrm{~m})$. Note the good correlation of $\mathrm{CH}_{4}$ and temperature anomalies. The vertical dotted line (triangles) represents the typical background of $\mathrm{CH}_{4}$ profile in deep Atlantic waters $\left(6-8 \mathrm{nl}\right.$ ) (see Hy14 station on Fig. 2). The star $\left(^{*}\right)$ represents a sample taken at $2500 \mathrm{~m}$ depth at station TAG-ST2-CTD2 (LAT: 2609.50' LONG: $44^{\circ} 48.40 \mathrm{~W}$ ).

10 times greater than normal $\mathrm{CH}_{4}$ concentrations in deep waters and similar to EPR $\mathrm{CH}_{4}$ anomalies.

Cast station ST6-CTD26 (Fig. 4). $\mathrm{CH}_{4}$ concentration increases from $8 \mathrm{nl} / 1$ at $2500 \mathrm{~m}$ to $52 \mathrm{nl} / \mathrm{l}$ at $3578 \mathrm{~m}$ and $105 \mathrm{nl} / 1$ at $3450 \mathrm{~m}$. After this maximum located at $238 \mathrm{~m}$ above the bottom, the $\mathrm{CH}_{4}$ concentration decreases to around $58 \mathrm{nl} / 1$ at $3641 \mathrm{~m}(47 \mathrm{~m}$ above the bottom). Like in CTD-9, the $\mathrm{CH}_{4}$ plume is spreading over $400 \mathrm{~m}$ above the sea floor. The $\mathrm{CH}_{4}$ anomaly at $3450 \mathrm{~m}$ correlates with positive temperature anomaly (about $0.05^{\circ} \mathrm{C}$ ). Very high $\mathrm{CH}_{4}$ concentrations have been analyzed on two samples taken at $3672 \mathrm{~m}$ and $3676 \mathrm{~m}(12 \mathrm{~m}$ and $16 \mathrm{~m}$ above the sea floor). On the chromatographic recording, these $\mathrm{CH}_{4}$ peaks show similar integrated areas corresponding to respective concentrations of 2402 and $2422 \mathrm{nl} / \mathrm{l}$. These two very high $\mathrm{CH}_{4}$ values correlate with an increase of $i n$ sit $u$ temperature from $2.680^{\circ} \mathrm{C}$ to $3.029^{\circ} \mathrm{C}(\Delta t=$ $0.349^{\circ} \mathrm{C}$ ) at $5 \mathrm{~m}$ above the sea floor.

The $\mathrm{CH}_{4}$ concentrations at ST6-CTD26 are about 400 times greater than typical $\mathrm{CH}_{4}$ concentrations of deep Atlantic waters. These samples were collected with the CTD/Rosette system within tens of meters of a black smoker: despite this high $\mathrm{CH}_{4}$ concentration compared to sea water, this result shows how rapid is the dilution of hydrothermal fluids with sea water, since $\mathrm{CH}_{4}$ concentrations in the hydrothermal 

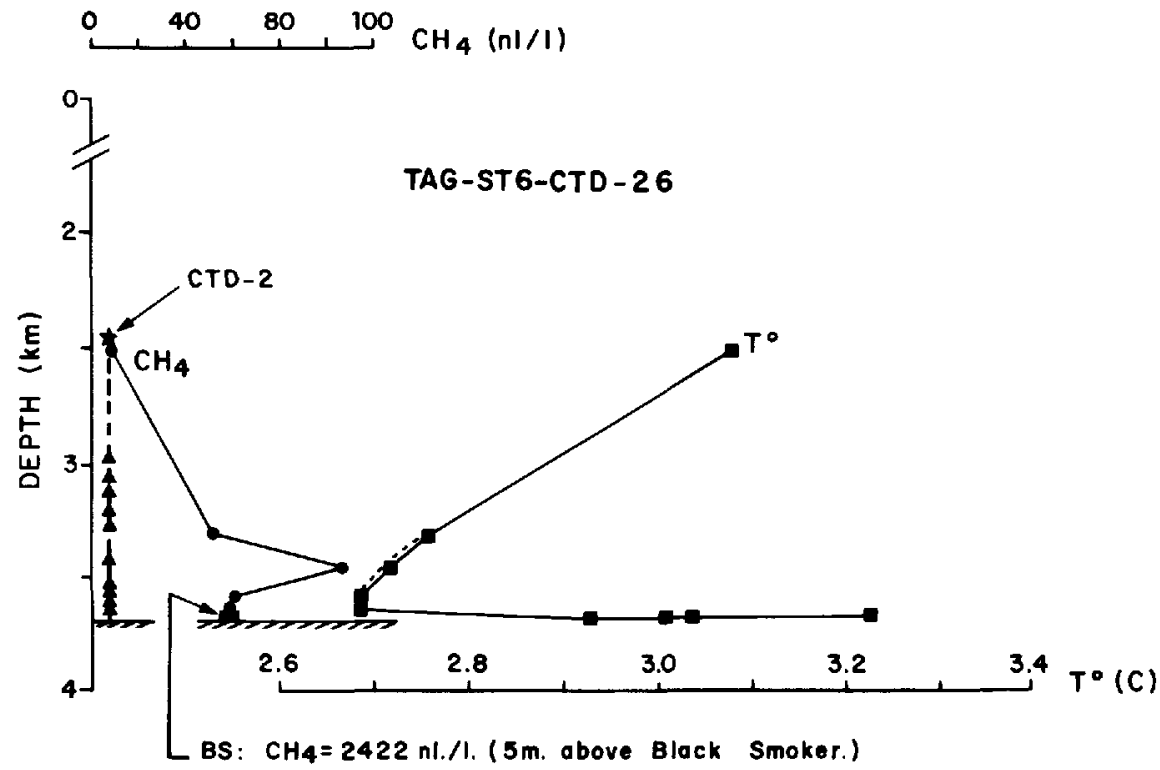

Figure 4. Cast station-ST6-CTD26: Lat: $26^{\circ} 08.28^{\prime} \mathrm{N}$; Long: $44^{\circ} 49.65^{\prime} \mathrm{W}$. In situ temperature $\left({ }^{\circ} \mathrm{C}\right)$ and methane concentration $(\mathrm{nl} / \mathrm{l})$ are represented versus depth $(\mathrm{km})$. The hatched lines indicate the bottom depth $(3688 \mathrm{~m})$. Note the good correlation of a $\mathrm{CH}_{4}$ anomaly $(105 \mathrm{nl} / 1)$ with a water temperature anomaly (about $\left.0.02^{\circ} \mathrm{C}\right)$ at $3450 \mathrm{~m}$ depth. At $3676 \mathrm{~m}(12 \mathrm{~m}$ above the sea floor) the large temperature anomaly $\left(\Delta t=+0.55^{\circ} \mathrm{C}\right.$; highest measured temperature was $3.37^{\circ} \mathrm{C}$ ) corresponds to large concentration of $\mathrm{CH}_{4}$ (up to $2422 \mathrm{nl} / \mathrm{l}$ ) in two seawater samples taken just over the black smokers (BS). The sample taken at $3298 \mathrm{db}$ depth is located at $150 \mathrm{~m}$ from vent. The vertical dotted line (triangles) represents the typical background $\mathrm{CH}_{4}$ profile in deep Atlantic waters (6-8 nl/l) (see Hyl4 station on Fig. 2). The star $\left(^{*}\right)$ represents a sample taken at $2500 \mathrm{~m}$ depth at station TAG-ST2-CTD2 (Lat:26 ${ }^{\circ} 09.50^{\prime} \mathrm{N}$; LONG: $44^{\circ} 48.40^{\prime} \mathrm{W}$ ).

fluids are presently about $1-2 \mathrm{ml} / \mathrm{l}$. It also demonstrates that a very large contrast between hydrothermal fluids and sea water is required before an element or compound can be used to identify plumes.

\section{Conclusions}

Methane measurements made on water samples collected near black smokers at the junction of the base of the east wall and the floor of the rift valley, near $26^{\circ} 08^{\prime} \mathrm{N}$, $44^{\circ} 49^{\prime} \mathrm{W}$, contiguous with a previously known zone of low temperature hydrothermal activity higher on the east wall, confirm the presence of a significant excess of $\mathrm{CH}_{4}$ which is correlated with temperature anomalies (Rona, 1985) and excess of dissolved manganese (Klinkhammer et al., 1985b), particulate iron, and total suspended matter (Trefry and Trocine, 1985). 
The magnitude of these $\mathrm{CH}_{4}$ excesses (up to $105 \mathrm{nl} / 1$ ) in the seawater column, 200 to $400 \mathrm{~m}$ above the sea floor and especially the high $\mathrm{CH}_{4}$ concentrations (around $2400 \mathrm{nl} / \mathrm{l}$ ) found in two samples collected 10-15 m near the bottom (CTD26), are consistent with the presence of ongoing and well developed hydrothermal activity at this site, on the Mid Atlantic Ridge, similar to sites on the East Pacific Rise. These $\mathrm{CH}_{4}$ concentrations are the largest $\mathrm{CH}_{4}$ anomalies measured on samples collected by a surface ship with CTD/Rosette in the seawater column near the sea floor.

The largest $\mathrm{CH}_{4}$ excesses, extending from 200 to $400 \mathrm{~m}$ above the bottom, show a significant vertical $\mathrm{CH}_{4}$ gradient at the site studied. $\mathrm{CH}_{4}$ concentrations up to $60 \mathrm{nl} / 1$ and elevated values of manganese (Klinkhammer et al., 1985) measured $400 \mathrm{~m}$ above the sea floor in the two profiles indicate that these MAR vents generate buoyant plumes similar to those observed over the EPR. Horizontal mixing and advection also occur.

The large vertical extent of the $\mathrm{CH}_{4}$ anomaly suggests continuous long term injection of fluids, involving an enrichment of sediment with pure hydrothermal metalliferous precipitates $(\mathrm{Cu}, \mathrm{Fe}, \mathrm{Mn}, \mathrm{Zn}$ ) within $2 \mathrm{~km}$ of the vent field (Trefry et al., 1986). The $\mathrm{CH}_{4}$ results obtained on seawater samples from the MAR between 12 and 15N (Charlou et al., 1986a) and the samples studied here, show that active vents are present on slow spreading ridges that are similar to those on fast spreading ridges. On the EPR, the most recent volcanic activity primarily occurs in a faulted axial valley associated with metalliferous sulfide deposits. Hydrothermal edifices constructed of hydrothermal precipitates are present at a water depth of about $2600 \mathrm{~m}$. On MAR, up to now, fluid emission has been found rising on the walls of the rift from a depth of about $3600 \mathrm{~m}$ (Charlou et al., 1986a; this work); subsequent to this discovery at the TAG site, black smokers were found $310 \mathrm{~km}$ to the south at $3600 \mathrm{~m}$ at the axis of the rift valley of the Mid Atlantic Ridge (Leg 106 Scientific Drilling Party, 1986), indicating the high temperature hydrothermal venting may be a general feature of slow, as well as fast spreading oceanic ridges. Looking at the similarities of $\mathrm{CH}_{4}$ profiles in the seawater column above active vents at sites on the two different types of ridges, we conclude that hydrothermal fluids of the MAR seem to be as enriched in $\mathrm{CH}_{4}$ as hydrothermal fluids of the EPR. In order to compare the total $\mathrm{CH}_{4}$ input along slow and fast spreading systems, it will be necessary to know the frequency of active vents along the ridge and the nature of emanating fluids. Therefore, collection of fluids by submersible is needed to advance knowledge of the hydrothermal exchange processes on slow spreading oceanic ridges. The high $\mathrm{CH}_{4}$ concentrations found over the vents of $26 \mathrm{~N}$ (TAG) indicate high temperature fluid injection comparable to high fluid injection of EPR. Analysis of the first hydrothermal fluid samples obtained in May/June of 1986 from two active vent sites at 26N(TAG) and 23N(MARK) on MAR confirm these observations. Despite the greater depth of these vents $(3700 \mathrm{~m})$ relative to those at $21 \mathrm{~N}$ or $13 \mathrm{~N}$ on EPR $(2600 \mathrm{~m})$, they display similar high temperature $\left(300-350^{\circ} \mathrm{C}\right)$ and similar fluid composition (Edmond et al., 1986). So, 
high temperature venting on slow spreading ridges appears to be common. These first methane data in the seawater column associated to chemical data of hydrothermal fluids, contribute to our understanding of the role of pressure on the behavior of the fluids during seawater-rock interaction on fast and slow ridges.

Acknowledgments. The seawater samples analyzed were collected as part of a NOAA VENTS PROGRAM Cruise of the NOAA ship Researcher in July-August, 1985. We thank J. H. Trefry of Florida Institute of Technology for drawing the samples.

\section{REFERENCES}

Atkinson, L. P. and F. P. Richards. 1967. The occurrence and distribution of $\mathrm{CH}_{4}$ in the marine environment. Deep-Sea Res. 14, 673-684.

Baker, E. T., J. W. Lavelle and C. J. Massoth. 1985. Hydrothermal particles plumes over the southern Juan de Fuca Ridge. Nature, 216, 342-344.

Boulegue, J. and B. Hamelin. 1983. Activité hydrothermale de la dorsale Pacifique Est à $21^{\circ} 30^{\prime} \mathrm{S}$ d'après les profils de concentration du manganèse dans l'eau de Mer. CRAS, 297, 671-674.

Boulegue, J., G. Michard, H. Bougault and J. L. Charlou. 1980. Hydrothermal activity on the East Pacific Rise between $15^{\circ} \mathrm{N}$ and $7^{\circ} \mathrm{S}$. EOS, 61, 992.

Brooks, J. M. and W. M. Sackett. 1973. Sources, sinks and concentrations of light hydrocarbons in the Gulf of Mexico. J. Geophys. Res., 78, 5248-5258.

Burke, R. A. et al. 1981. Light hydrocarbons in Red Sea brines and sediments. Geochim. Cosmochim. Acta, 45, 627-634.

Charlou, J. L., H. Bougault and L. Dmitriev. 1986a. $\mathrm{CH}_{4}$ plume between $12^{\circ}$ and $15^{\circ} \mathrm{N}$ over MAR. EOS., 67, 365.

Charlou, J. L., L. Dmitriev, H. Bougault and H. D. Needham. 1986b. Hydrothermal $\mathrm{CH}_{4}$ between $12^{\circ}$ and $15^{\circ} \mathrm{N}$ over the Mid Atlantic Ridge. (submitted).

Craig, H. and J. E. Lupton. 1981. Helium-3 and mantle volatiles in the ocean and the oceanic crust, in The Sea, vol. 7, The Oceanic Lithosphere, C. Emiliani, ed., Wiley Interscience Publication, John Wiley and Sons, 391-428.

Cronan, D. S., P. A. Rona and S. Sharme. 1979. Metal enrichments from the TAG hydrothermal field. Marine Mining, 2, 79-89.

Edmond, J. M., A. C. Campbell, M. R. Palmer and G. P. Klinkhammer. 1986. Preliminary report on the chemistry of hydrothermal fluids from the Mid Atlantic Ridge. EOS, 67, 1021.

Edmond, J. M., K. L. Von Damn, R. E. Mac Duff and C. S. Measures. 1982. Chemistry of hot springs on the East Pacific Rise and their effluents dispersal. Nature, 297, 187.

Jenkins, W. J., M. A. Beg, W. B. Clarke, P. J. Wangersky and H. Craig. 1972. Excess ${ }^{3} \mathrm{He}$ in the Atlantic Ocean. Earth, Planet. Sci. Lett., 16, 122-126.

Jenkins, W. J., P. A. Rona and J. M. Edmond. 1980. Excess ${ }^{3} \mathrm{He}$ in the deep water over the Mid Atlantic Ridge at $26^{\circ} \mathrm{N}$. Evidence of hydrothermal activity. Earth, Planet. Sci. Lett., 49, $39-44$.

Kim, K. R. 1983. Methane and radioactive isotopes in submarine hydro-thermal systems. PhD thesis, University of California, San Diego.

Kim, K. R., J. A. Welhan and H. Craig. 1984. The hydrothermal vent fields at $13^{\circ} \mathrm{N}$ and $11^{\circ} \mathrm{N}$ on the East Pacific Rise: Alvin 1984 results. EOS, 68, 45.

Klinkhammer, G., P. Rona, H. Elderfield and M. Greaves. 1985a. Seawater manganese anomalies associated with active hydrothermal vents in the Mid Atlantic Ridge rift valley. EOS, 66, 936 . 
Klinkhammer, G., P. Rona, M. Greaves and H. Elderfield. 1985b. Hydrothermal manganese plumes in the Mid Atlantic Ridge rift valley. Nature, 314, 727-731.

Kong, L. et al. 1985. Bare rock drill sites, ODP legs 106 and 109: evidence for hydrothermal activity at $23^{\circ} \mathrm{N}$ on the Mid Atlantic Ridge. EOS, 66, 46.

Lamontagne, R. A. et al. 1973. Methane concentrations in various marine environments. J. Geophys. Res., 78, 5317-5324.

Leg 106 Scientific Drilling Party. 1986. Drilling succeeds on bare rock. Geotimes 31(5).

Lilley, M. D., J. A. Baross and L. I. Gordon. 1983. Reduced gases and bacteria in hydrothermal fluids: the Galapagos spreading center and $21^{\circ} \mathrm{N}$ East Pacific Rise, in Hydrothermal Processes at Seafloor Spreading Centers, P. A. Rona, K. Boström, L. Laubier, and K. L. Smith, Jr., eds., NATO Conference series IV, Marine Sciences, 12, New York Plenum Press, 411-449.

Lilley, M. D., M. De Angelis and L. I. Gordon, 1979. $\mathrm{CH}_{4}, \mathrm{He}$, $\mathrm{Co}$ and $\mathrm{N}_{2} \mathrm{O}$ in submarine hydrothermal vent waters. Nature, 300, 48-50.

Lonsdale, P. and K. Becker. 1985. Hydrothermal plumes, hot springs and conductive heat flow in the southern trough of Guaymas basin. Earth, Planet. Sci. Lett., 73, 211-215.

Lonsdale, P., J. L. Bishoff, V. M. Burns, M. Kastner and R. E. Sweeney. 1980. A high temperature hydrothermal deposit on the seabed at a Gulf of California spreading center. Earth, Planet. Sci. Lett., 49, 8-20.

Lowell, R. P. and P. A. Rona. 1976. On the interpretation of near bottom water temperature anomalies. Earth, Planet. Sci. Lett., 32, 18-24.

Lupton, J. E. 1979. Helium 3 in the Guaymas basin: evidence for injection of mantle volatiles in the Gulf of California. J. Geophys. Res., 84, 7446.

Lupton, J. E. and H. Craig. 1981. A major helium-3 source at $15^{\circ}$ S on the East Pacific Rise. Science, 214, 13-18.

Lupton, J. E., G. P. Klinkhammer, W. R. Normark, R. Haymon, K. Macdonald, R. Weiss and H. Craig. $1980 .{ }^{3} \mathrm{He}$ and manganese at the $21^{\circ} \mathrm{N}$ EPR hydrothermal site. Earth, Planet. Sci. Lett., 50, 115-127.

Merewether, R., M. Olson and P. Londsdale. 1985. Acoustically detected hydrocarbon plumes rising from $2 \mathrm{~km}$ depths in Guaymas basin, Gulf of California. J. Geophys. Res., 90, 3075-3085.

Metz, S. and J. H. Trefry. 1985. Geochemistry of metalliferous sediments from the TAG hydrothermal field, Mid Atlantic Ridge. EOS, 66, 46.

Michard, G., F. Albarede, A. Michard, J. F. Minster, J. L. Charlou and N. Tan. 1984. Chemistry of solutions from the $13^{\circ} \mathrm{N}$ East Pacific Rise hydrothermal site. Earth, Planet. Sci. Lett. 67, 297-307.

Nelsen, T. A., G. Klinkhammer and D. Trefry. 1985. Real time observation and tracking of hydrothermal plumes on the Mid Atlantic Ridge. EOS, 66, 936.

Normark, W. R. et al. 1982. Polymetallic sulfide deposits and water column of active hydrothermal vents on the southern Juan de Fuca Ridge. Mar. Technol. Soc. J., 16, 46-53.

Rona, P. A. 1985. Black smokers and massive sulfides at the TAG hydrothermal field Mid Atlantic Ridge $26^{\circ} \mathrm{N}$, EOS., $66,46$.

- 1978. Near bottom water temperature anomalies: Mid Atlantic Ridge crest at latitude $26^{\circ} \mathrm{N}$. Geophys. Res. Lett., 5, 993-996.

Rona, P. A., G. Klinkhammer, T. A. Nelsen, J. H. Trefry and H. Elderfield. 1986. Black smokers, massive sulfides and vent biota at the Mid Atlantic Ridge. Nature, 321, 33-37.

Rona, P. A., G. Thompson, M. J. Mottl, J. A. Karson, W. I. Jenkins, D. Graham, M. Mallette, K. Von Damn and J. M. Edmond. 1984. Hydrothermal activity at the Trans-Atlantic 
Geotraverse Hydrothermal Field, Mid Atlantic Ridge Crest at $26^{\circ} \mathrm{N}$. J. Geophys. Res., 89 , 11365-11377.

Scott, R. B. et al. 1974. The TAG hydrothermal field. Nature, 251, 301-302.

Scranton, M. and P. G. Brewer. 1977. Occurrence of $\mathrm{CH}_{4}$ in the near surface waters of the western subtropical north Atlantic. Deep-Sea Res., 24, 127-138.

1978. Consumption of dissolved methane in the deep ocean. Limnol. Oceanogr., 23, 1207-1213.

Swinnerton, J. W., W. Linnenbom and C. H. Cheek. 1962. Determination of dissolved gases in aqueous solutions by gas chromatography. Anal. Chem., 34, 483-485.

Trefry, J. H., S. Metz, R. P. Trocine and T. A. Nelsen. 1986. Geochemistry and history of hydrothermal precipitates in a Mid Atlantic vent Field. EOS, 67, 1022.

Trefry, J. H. and R. P. Trocine. 1985. Distribution and chemistry of particles from an active vent site on the Mid Atlantic Ridge. EOS, 66, 936.

Weiss, R. F. 1977. Hydrothermal manganese in the deep sea: scavenging residence time and $\mathrm{Mn} /{ }^{3} \mathrm{He}$ relationships. Earth, Planet. Sci. Lett., 37, 257-262.

Welhan, J. A. and H. Craig. 1979. Methane and hydrogen in East Pacific Rise hydrothermal fluids. Geophys. Res. Lett., 6, 829.

1983. Methane, hydrogen and helium in hydrothermal fluids at $21^{\circ} \mathrm{N}$ on the East Pacific Rise, in Hydrothermal Process at Seafloor Spreading Centers, Rona et al., eds., NATO Conference Series 4, Marine Sciences 12, Plenum Press, NY, 391-409.

Welhan, J. A., H. Craig and K. Kim. 1984. Hydrothermal gases at $11^{\circ} \mathrm{N}$ and $13^{\circ} \mathrm{N}$ on the East Pacific Rise. EOS, 65, 45.

Welhan, J. A. and J. E. Lupton. 1987. Light hydrocarbon gases in Guaymas Basin hydrothermal fluids: thermogenic v.s. abiogenic origin. A.A.P.G. Bull., 7l, 215-223.

Received: 30 July, 1986; revised: 17 February, 1987. 